\title{
Влияние русского языка на белорусские говоры (на примере полевых исследований в Мядельском районе Минской области)
}

\section{The influence of the Russian language on contemporary Belarusian dialects (on the example of field research carried out in Myadzyel district in the Minsk region)}

\begin{abstract}
The aim of this article is to describe the role of the Russian language in a multilingual environment, which is the Belarusian-Polish-Lithuanian borderland. The study pays particular attention to the influence of the Russian language on contemporary Belarusian dialects, in particular on the Central Belarusian dialect. Part of the Central Belarusian dialect is the dialect of Kamarova (Myadzel district, Minsk region), where I have conducted field research since 2010. The article provides an analysis of selected fragments from the interviews with local residents, indicating a significant impact of the Russian language (primarily at the lexical level) on the speech of the residents of Kamarova, regardless of their age, education, status, position, etc. Moreover, the long and continuing influence of the Russian language on Belarusian dialects, its strong position in Belarus and its high prestige suggest a change in the dialect of Kamarova, in which lexical elements of the Polish/ Lithuanian language are gradually being replaced by their Russian equivalents.
\end{abstract}

Keywords: Belarusian dialects, Belarusian-Polish-Lithuanian borderlands, Komarovshchizna, Myadzel district, Minsk region

Anna Żebrowska, Uniwersytet im. Adama Mickiewicza w Poznaniu, Poznań - Polska, zanna@amu.edu.pl, ORCID ID: https://orcid.org/0000-0003-2551-3753

\section{Введение}

Белорусско-литовско-польское пограничье представляет собой многоэтнический, многоязычный и многокультурный ареал, являющийся объектом исследования историков, этнологов, культурологов, лингвистов и специалистов многих других областей. Исследованиям этой проблематики, охватывающей разносторонние языковые аспекты, посвящены многочисленные 
работы как польских (Bednarczuk 1999, 2010; Engelking 2000, 2006, 2012; Golachowska 2010, 2012; Radzik 2000a, 2000b; Smułkowa 2002, 2007, 2009, 2010, 2011, 2016; Zielińska 2002, 2008, 2012 и мн. др.), так и зарубежных исследователей (Astrèjka 2010, 2013; Budźko; Cyhun 2018; Erker 2013, 2014; Guszczewa; Smalanczuk; Wiemer 2003, 2006).

Особую ценность представляют работы известного польского диалектолога, слависта Эльжбеты Смулковой, руководившей рядом полевых исследований, результатом которых стали обширные монографии Pogranicza Białorusi w perspektywie interdyscyplinarnej (Smułkowa 2007) и Brasławszczyzna. Pamięć i współczesność в двух томах (Smułkowa 2009, 2011). Вторую работу (Brasławszczyzna...) Смулкова называет научно-исследовательской лабораторией северо-западного участка данного пограничья, направленной „przede wszystkim na poznanie i przedstawienie aktualnego stanu językowego regionu, zwłaszcza słownictwa, ze szczególnym zwróceniem uwagi na zakres użycia i charakterystykę mówienia po polsku i po tutejszemu, po białorusku, jako środków komunikacji dla tego terenu od dawna podstawowych" (Smułkowa 2011: 8).

Значение междисциплинарных исследований на Браславщине подчеркивалось как польскими (Barszczewska; Karaś; Zielińska 2013), так русскими (Tolstaâ) и белорусскими (Суhun 2011) исследователями. На основании проведенного анализа двухтомной публикации Brasławszczyzna... и доступных на нее рецензий, вне всякого сомнения, можно констатировать, цитируя российского лингвиста Светлану Толстую, что „все дальнейшие исследователи этого региона уже не смогут обойтись без обращения к этому фундаментальному труду, созданному совместными усилиями польских и белорусских диалектологов и изданному в Варшаве” (Tolstaâ 198). Необходимо отметить, что данное издание чрезвычайно значимо также для исследования других регионов, расположенных на пограничье языков и культур, в том числе Комаровщизны ${ }^{1}$ (д. Комарово и ряд окрестных деревень), где с 2010 года нами проводятся полевые исследования. Именно на этой территории и сфокусируются наши дальнейшие рассуждения, целью которых является: 1) краткая историческая характеристика исследуемого ареала; 2) социолингвистическая ситуация данной местности и 3) представление влияния русского языка на современный диалект, функционирующий на этой территории.

${ }^{1}$ В соответствии с правилами русского языка польское название Komarowszczyzna должно переводиться как Комаровщина. В нашей статье оно выступает как Комаровщизна, поскольку в архивных русскоязычных источниках данная местность выступает именно под таким названием. 


\section{Расположение и историческая характеристика Комаровщизны}

Комаровщизна расположена в северо-западной Беларуси по знаменитому Полоцкому тракту (сейчас - автомобильная трасса Вильнюс - Полоцк), в 40 километрах от литовской границы, 80 км от Вильнюса и 180 км от Минска. Исследуемая территория, находясь в Мядельском районе Минской области, граничит с Вилейским районом этой же области, Поставским и Докшицким районами Витебской области, Островецким и Сморгонским Гродненской области.

Комаровщизной ранее называли поместье, восходящее к XIV веку. Усадьба на протяжении шести столетий меняла своих владельцев и принадлежала таким известным родам, как Гаштольды, Котлы, Радзивиллы, Комары, Козел-Поклевские, Хоминские, Пашкевичи, Борткевичи, Бениславские и Старжинские. Последними ее владельцами - с конца XIX в. (1888) и до начала Второй мировой войны (1939), был дворянский род Старжинских (Gìl', Draǔnìckì 22-24). В 1939 г., после вступления Красной армии, имущество было разграблено, а хозяйство стало частью колхоза (сначала „17 Сентября”, а затем „Константиново”). Позже (1996) к Комарову была присоединена соседняя деревня Кутьки, в настоящее время на белорусских картах отмеченная под названием д. Комарово, а среди местных жителей называемая по-прежнему Кутьки. В наших исследованиях Комаровщизна имеет символический характер, поскольку название относится не только к д. Комарово, но и к окрестным деревням (Бакшты, Богатьки, Борисы, Венцевичи, Ворошилки, Грумбиненты, Константиново, Куркули, Нарейши, Нетьки, Ольшево, Семки, Старая, Фалевичи, Януковичи, Яцыны). В настоящее время перечисленные местности являются частью Свирского сельсовета Мядельского района Минской области, ранее они входили в состав Свенцянского уезда Виленской губернии.

За свою многовековую историю (XIV-XIX вв.) Комаровщизна меняла не только владельцев, но и общественно-политическую систему. Согласно историческим данным (Lemâšonak; Draǔnìckì; Gìl', Draǔnìckì), поместье Комарово сформировалось до 1330 года и входило в состав Полоцкого княжества. Полоцкое княжество, а вместе с ним и вся Мядельщина, вплоть до XVI в. было частью Великого княжества Литовского (ВКЛ), возникшего в XIII веке в результате объединения славянско-литовских племен. C XVI-го по XVIII век мядельские земли входили в состав Речи Посполитой. После ее раздела власть на Мядельщине менялась еще несколько раз: сначала она принадлежала Российской империи, затем, после заключения Рижского договора, Польше, позднее Белорусской ССР, немецким оккупантам и снова Советскому Союзу. В 1991 году, после распада СССР, Беларусь была про- 
возглашена независимой республикой, которой остается до настоящего времени.

Передвижение границ, а также неоднократная смена властей, вызывавшая то полонизацию, то русификацию местного населения, отразилась на формировании традиций данного региона и, несомненно, на местной разновидности белорусского языка, называемой самими жителями простай мовай, сваей, вясковай.

\section{Социолингвистическая ситуация Комаровщизны}

Языковая ситуация исследуемой территории, подобно как и современной Беларуси, отличается неоднородностью. Она характеризуется наличием нескольких языковых систем, образовавшихся в результате взаимодействия белорусского, русского, польского и литовского языков.

Белорусский язык представлен литературным белорусским языком и местным говором. В степени владения русским языком также наблюдается вариативность форм: от литературного языка с незначительными белорусскими интонационными особенностями до смешанной речи. Кроме того, Комаровщизна как и вся Мядельщина, расположенная в северо-западной Беларуси, в силу своей исторической судьбы относится к региону, который в прошлом был частью Польши, поэтому здесь и в настоящее время отмечается влияние польского языка. Однако его роль сводится в основном к символической функции, заключающейся в том, что в сознании человека сохраняется польское происхождение (у многих имеются в наличии документы, подтверждающие этот факт), традиции, переданные предками, и чувство связи с Польшей. При этом знание польского языка преимущественно ограничивается пониманием, а его использование - конфессиональной сферой. Близость границ с Литвой объясняет наличие в речи местного населения элементов литовского языка, которое наблюдается прежде всего в речи старшего поколения и проявляется на лексическом уровне в заимствовании отдельных выражений (например, абжаргащь - рус. оседлать коня, переступить через что-л.; бразгачь - рус. стучать; говорить невнятно, быстро; дзірван - рус. залежные земли; кумпяк - рус. ветчина, окорок и мн. др.).

Анализ собранного материала указывает на то, что коренные жители в основном пользуются местным говором, сложившимся под влиянием польского, русского, белорусского и литовского языков. При этом в речи его носителей в зависимости от возраста отмечаются некоторые различия. Например, язык старшего поколения представляет собой смешение польского и белорусского языков с незначительным количеством русской 
лексики; среднее поколение старается общаться на белорусском литературном языке, однако в некоторых ситуациях - в банке, в магазине, на почте, в беседе с представителями власти и т. п. - на русском с фонетическими, а нередко и лексическими особенностями белорусского языка. В речи отдельных информантов чувствуется также влияние польского языка. Однако следует подчеркнуть, что жители, родившиеся после Второй мировой войны и получившие среднее или высшее образование, способны разграничивать белорусский литературный язык, русский и местный говор. Поэтому высказывания среднего поколения характеризуются большей чистотой языка, чем высказывания старожилов. Дети и молодежь в школе, на уроках, говорят на белорусском или русском литературном языке; на перемене и вне школы (между собой) - преимущественно на русском; с родителями или жителями деревни, исходя из сложившихся обстоятельств, - на русском языке или на местном говоре.

Такое распределение находит свое подтверждение в примерах, которые приводятся и анализируются в дальнейшей части статьи. Принимая во внимание тему данных рассуждений и объем статьи, мы сосредоточимся исключительно на влиянии русского языка, наблюдающемся в речи жителей Комаровщизны. Взаимодействия с другими языками (польским и литовским) представлены в монографии Komarowszczyzna. Język pogranicza białorusko-polsko-litewskiego (Żebrowska).

\section{Русский язык и говор жителей Комаровщизны}

Русский язык, являющийся одним из государственных языков и пользующийся огромным престижем среди белорусских граждан, играет неоспоримую роль в формировании современной социолингвистической ситуации Беларуси. Его влияние заметно во всех направлениях и областях человеческой деятельности, независимо от общественного статуса, профессии, возраста, образования и других факторов (ср. Guszczewa). Свое отражение оно находит также в речи сельских жителей, что попытаемся показать, приводя фрагменты высказываний представителей разных поколений (младшего, рожденного в 1970-2000-х гг.; среднего, рожденного после Второй мировой войны; старшего, рожденного в довоенный период), живущих в деревне Комарово и окрестных деревнях. Влияние русского языка на белорусскую речь коренных жителей исследуемого ареала в основном проявляется на лексическом уровне, хотя, несомненно, существуют примеры фонетической и грамматической интерференции (cp. Guszczewa 230). Принимая во внимание наличие частотности и интенсивности лексических заимствований в речи 
жителей Комаровщизны, в данной статье мы сосредоточимся исключительно на них.

Речь младшего поколения, в сравнении со средним и старшим, характеризуется наибольшим присутствием русского языка в жизни молодых жителей Комаровщизны, а его влияние проявляется как в официальных, так и в неофициальных сферах общения. Оно заметно также и в местном говоре, которым молодые люди пользуются в сфере семейного и соседского общения. Примером этому послужат фрагменты бесед с представителями данного поколения.

Первое из них принадлежит молодому человеку в возрасте 28 лет. Языком его повседневной коммуникации является местный говор, вне сферы семейного общения данный респондент пользуется русским языком.

(1) Я приеду гдзе-та читырнацтава августа, а патом уже будзем сматреть, как там палучицца² (Комарово, мужчина, 1991 г. р.).

(2) Ну ні знаю, як сказаць... гэта цяшка яб 'ясніщъ. Карані ў мяне польскія, дзетка і бапка некалі гаварылі па-польску. Гэта даўней. 3 намі ўжо не. [...] 3 намі, так як цяпер гаворым, па просту, па-свойму. Нас ужо ні вучылі па-польску. Многа маіх друзей ездзіць у Польшчу, у Беласток ці куды там, алі ні па музеях хадзіць, толькі купіць - прадаць і назат. Ёсь многа й такіх, каторыя работаюиьь у Польшчы ці ў Літве (Комарово, мужчина, 1991 г. р.).

Первая цитата была услышана и записана во время беседы респондента со своим другом. Вторая - взята из проведенного нами интервью. Нетрудно заметить, что в первом случае (1) автор цитаты пользуется русским языком, в котором заметно фонетическое влияние белорусского; во втором (2) - этот же респондент использует белорусский язык, в котором прослеживается лексическая интерференция: аб'ясніць вместо бел. растлумачьць; друзей вместо бел. сяброй; работаюць вместо бел. праиуюизь. Объяснить это можно тем, что интервью проводилось нами на белорусском языке, тогда как собеседник нашего респондента пользовался русским языком. Подобная ситуация достаточно распространена и вполне натурально воспринимается жителями исследуемого ареала. Сказанное подтверждается очередным высказыванием (3), характеризующим речь женщины, рожденной в 1984 году и в неофициальной сфере общения также пользующейся белорусским диалектом. В нем мы отметили такие русизмы как: ні нада вместо бел. ні трэба; зачем вместо бел. навошта; так вместо бел. дык; ложка вместо бел. льжка; у шкафу вместо бел. у шафе.

2 Запись всех приведенных фрагментов высказываний жителей Комаровщизны отражает фактическое произношение слов и выражений. 
(3) Ай, ну ні нада гаварыць таго, чаго ні было. Скажы, вот зачем мне выдумваць, раз ты ні брала, так што гэта ложка робіць у маім шкафу (Комарово, женщина 1984 г. р.).

Влияние русского языка заметно также в речи представителей среднего поколения, причем его проявление характерно как для жителей с высшим образованием, в том числе учителей белорусского языка или истории Беларуси, так и для респондентов со средним и специальным образованием. Вначале предложим фрагмент из высказывания женщины со среднеспециальным образованием, работающей секретарем в профессиональном училище в Комарово (4), а затем учительницы, преподающей историю Беларуси в белорусскоязычной школе (5):

(4) Дзеці ні чытаюць, колькі вы чыталі, ці помніш, сколькі ты чатала, сколькі ты прынасіла журналаў, кніжак ні было. Я пачынала 3 вамі [работать - пояснение автора, А.Ж.], кніжак ні было, толькі ўвялі гісторыю Беларусі. Я ш помню, як вы кніжкамі мяняліся, художыственную ліщературу чыталі. [...] А што ш, мы пачщі, ну яшчэ калі пара школ у раёне, так мала ш беларускамоўных і ёсь, $\partial a$, вот мы вот застаёмся беларускамоўнай школай, а так шас усе памінялі на рускія. [...] Но і цяпер, кап дзеці усё тое бралі, што мы даём, кап яны хацелі гэта браць, дык ім бы тожа хватала. Другі вапрос у тым, што, ну, так (Куркули, женщина 1971 г. р.).

(5) Раўг[g]еня гэта з жытнёвай мукі [...], неяк яна заквашавалася і палучалася такая вот, ну, ні кісель, а іменна вот, ну, нешта, я ні магу табе аб'ясніць, я вот дажа прывкус вот [...]. А я тады ўжо стала ўзрастаць, тады ужо брусьніку мы зьбіралі, ў катлах варылі, вялікія такія вот, у вёдры налівалі, тожа ў посьце в аснаўном з бульбай гэту брусьніку мама ўсё, вадой разьвядуць і вот мы елі гэту брусьніку (Комарово, женщина 1955 г. р.).

Необходимо пояснить, что вторая респондентка родилась в польской католической семье. Ее родители общались на польском языке и строго придерживались польских традиций. Сама женщина пассивно владеет польским языком, а общаться старается на белорусском литературном языке, который, как вытекает из приведенной цитаты (5), не лишен влияния русского языка (палучалася вместо бел. атрылоўвалася; вот вместо бел. вось; іменна вместо бел. менавіта; аб'ясніцьь вместо бел. растлумачыць; дажабел. нават; прывкус - рос. привкус, бел. прысмак; брусьніка - рос. брусника, бел. брусніщы; тожа вместо бел. таксама; в аснаўном - рус. в основном, бел. у асноўнымм).

В речи учительницы также выступает русскоязычная лексика, несмотря на то, что существуют ее белорусские эквиваленты: журналь вместо бел. часопісы; художыственная ліиеература вместо бел. мастацккая літаратура; пачці вместо бел. амаль; да вместо бел. так; вот вместо бел. вось; шас разговорный вариант русского наречия сейчас - тогда как в белорусском языке выступает выражение цяяпер; тожа - рус. тоже, бел. таксама; хватала 
- вместо бел. хапала; вапрос - вместо бел. пытанне. Можно предположить, что причиной подобного языкового поведения является не отсутствие знаний о родном языке, поскольку неоднократно мы были свидетелями, когда в ситуациях, требующих официальной речи, респондентка пользовалась чистым белорусским литературным языком, - а сильная интерференция русского языка, присутствующего во всех коммуникационных сферах. Дополнительным фактором может быть также свободная обстановка общения и наше длительное знакомство, поскольку в таких ситуациях собеседник ведет себя естественно и не следит за своей речью.

Необходимо подчеркнуть, что большое количество русских заимствований наблюдается в речи респондентов, занимающих в свое время ту или иную должность (напр., директора, экономиста, бухгалтера и т. д.). Приведем пример из интервью с женщиной, работавшей экономистом в колхозе „Константиново”:

(6) Марына во мая званіла, кажыць, мама, у нас на рабоце обшчым вызвалі... гэты госкантроль, наляцелі усё трасець, апламбіраваны ўсе шчыта, палучкі ні даюць. Ні маюць чым плаціць. Казала ні знаю, што будзіць (Комарово, женщина 1957 г. р.).

В процитированном фрагменте (6) обнаружены такие лексемы, как: на рабоче вместо бел. на працы; обшчым - рус. в общем, бел. у агульным; гаскантроль вместо белорусского дзяржкантроль; апламбираваны шчыта рус. опломбированы счета, бел. апламбаваныя рахункі.

Идентичная закономерность прослеживается и в речи респондентов, рожденных в довоенный период:

(7) Ну дык вот карова была, малака было. Ну, эта такое вот, мама доіць карову, а мы ўтраёх стаім с крушкамі ўжо, малака этага. Ну, картошка ш, соткі ш тожа далі, картошка ш была, ужо свая. Во так і жылі. Дык я ціпер хлеба [...] нікагда ні выкіну (Куркули, женщина 1933 г. р.).

(8) Я тры класы польскай школы канчаў. І гэта было ўсё. Патом у вячэннюю схадзіў, болей нільзя ш было рабіџь на маей рабоце. Я рабіў дваццаць сем гадоў замдзірэктарам у вучылішчы. Гэдакая должнась і работа была сложная. I схадзіў можа у начале восем клас [...] (Комарово, мужчина 1929 г. р.).

Цитата (7) заключает в себе следующие лексемы, заимствованные из русского языка: вот - бел. вось; эта - рус. это, бел. гэта; с крушками - рус. с кружками, бел. з кубкамі; этага - рус. этого, бел. гэтага; картошка вместо бел. бульба; тожа вместо бел. таксама; нікагда вместо бел. ніколі. Этот фрагмент принадлежит женщине, которая родилась и всю жизнь прожила в деревне Куркули, однако, работая кассиром в местном колхозе, она вынуж- 
дена была пользоваться русским языком, что нашло свое отражение также в языке повседневного общения.

Автор последнего фрагмента (8), выполняя должность заместителя директора профессионального училища в д. Комарово, также был вынужден обращаться к русскому языку, поэтому и его местный говор не лишен русскоязычной лексики, например, вместо бел. пасля выступает рус. потом (в речи респондента патом); нільзя - рус. нельзя, бел. нельга; рабіuзь, работа вместо бел. працаваць, праца; замдзірэктар вместо бел. намеснік дырэктара; должнась - рус. должность, бел. пасада; сложная вместо бел. складаная; у начале - рус. в начале, бел. спачатку.

Нами приведены лишь избранные фрагменты высказываний, однако уже на их основании можно констатировать сильное, длительное и продолжающееся воздействие русского языка на белорусские говоры. Причем, как уже отмечалось ранее, оно затрагивает все сферы общения (образования, культуры, науки, массовой коммуникации, соседские, семейные и т. п.) и касается человека с любым социальным статусом, образованием, профессией, занимаемой должностью и т. п. В качестве доказательства мы приведем еще одно высказывание, принадлежащее учителю белорусского языка и литературы, в прошлом директора белорусскоязычной школы, истинного борца за белорусские традиции и культуру:

(9) Знаіця, што такое аiр? У балоце растуць такія [...] Яе ні было этай расьліны ў нас. Прывязьлі яе сюды татары. І гэта расьліна асаблівась такая, лто яна забівае бактэрыі. I вот, калі ў лужыне ці ў балаціне яе засадзілі, і каб ні захварэць дзізіньцірыяй ці якой хваробай, садзілі аір. I там, гдзе эты аір расьце, яны бралі ваду, сьмела пілі кіпячоную і ні хварэлі. Вот, што аір (Комарово, мужчина 1932 г. р.).

Данный фрагмент, так же, как и полное интервью с учителем, характеризуется наибольшей языковой чистотой, однако и в его речи выступают русизмы. В цитате (9) к ним относятся: это вместо бел. гэта; вот вместо бел. вось; гдзе - рус. где и бел. дзе. Наличие русскоязычной лексики в речи этого информанта дополнительно свидетельствует о существенном влиянии русского языка на белорусские говоры, а также подтверждает все сказанное до сих пор.

\section{Заключение}

Прослеживая социолингвистическую ситуацию Комаровщизны на протяжении всего периода полевых исследований (2010-2019 гг.) и анализируя собранный материал, можно заметить, что современный белорусский говор 
жителей деревни Комарово и окрестных деревень находится под существенным влиянием русского языка. Русский язык, являющийся важной составной достаточно сложной социолингвистической ситуации данного ареала, пользуется высоким престижем и употребляется практически во всех сферах общения.

Описывая место того или иного языка, характерного для многоязычной среды, необходимо учитывать как лингвистические, так и экстралингвистические факторы его развития и функционирования. Сферы употребления данного языка, степень владения им, индивидуальные возможности респондента, а также его возраст и социальный статус предопределяет состояние белорусской речи и наличие заимствованных компонентов из русского языка. Свидетельствует об этом ряд примеров, записанных нами в ходе полевых исследований, а также несколько приведенных в настоящей статье.

Проведенный анализ собранного материала позволяет говорить о влиянии русского языка на местный говор жителей Комаровщизны независимо от поколения, которое, в частности, проявляется на лексическом уровне. При этом насыщенность русской лексикой, как уже отмечалось, зачастую зависит от внеязыковых факторов, на что указывают, например, процитированные фрагменты (1-8).

Речь представителей молодого поколения характеризуется наибольшим присутствием русского языка, которое может колебаться от русского литературного языка с фонетическим влиянием белорусского до менее или более насыщенного русскоязычными заимствованиями белорусского говоpa (1-3). В говоре респондентов, рожденных в послевоенный и довоенный период, количество русской лексики зависит от образования и занимаемой должности (6-8), хотя, в той или иной степени, влияние русского языка на местный говор проявляется в речи каждого жителя исследуемого ареала $(4,5,9)$.

Длительное и продолжающееся воздействие русского языка на белорусские говоры, его сильная позиция в стране и высокий престиж позволяют говорить об изменении белорусского говора Комаровщизны, в котором лексические элементы польского/литовского языка постепенно заменяются русскими эквивалентами.

\section{Библиография}

Astrèjka, Vera. „Belaruskìa paǔnočna-zahodniâ zanal'nyâ moǔnyâ adroznennì âk vynìk règiânal'nyh ètna-kul'turnyh kantaktaǔ ì suvâzâŭ”. Acta Baltico-Slavica, nr 37, 2013, s. 311-322.

Astrèjka, Vera. „Slavâna-balckae leksičnae ǔzaemadzeânne ǔ gavorkah paǔnočna-zahodnâj dyâlektnaj zony belaruskaj movy”. Belaruskaâ lìngvistyka, vyp. 65, 2010, s. 11-19. 
Barszczewska, Nina. [Rec.]. „Brasławszczyzna. Pamięć i wspótczesność. Red. nauk. Elżbieta Smułkowa. T. 1. Historia regionu. Charakterystyka socjolingwistyczna. Świadectwo mieszkańców. Wydawnictwa Uniwersytetu Warszawskiego, Warszawa 2011, ss. 659. T. 2. Stownictwo dwujęzycznych mieszkańców rejonu (Stownik brasławski). Wydawnictwa Uniwersytetu Warszawskiego, Warszawa 2009, s. 765". Acta Albarutenica, t. 12, 2012, s. 261-266.

Bednarczuk, Leszek. Językowy obraz Wielkiego Księstwa Litewskiego. Kraków, Lexis, 2010.

Bednarczuk, Leszek. „Litewsko-słowiańskie pogranicze językowe w pierwszej połowie XX wieku w świetle badań Olgierda Chomińskiego". Acta Baltico-Slavica, nr 24, 1999, s. 95-105.

Budźko, Iryna. „Gwary białoruskie rejonu brasławskiego: geneza, geografia, uwarunkowania socjolingwistyczne”. Brasławszczyzna. Pamięć i współczesność. T. 1. Historia regionu. Charakterystyka socjolingwistyczna. Świadectwo mieszkańców. Red. nauk. Elżbieta Smułkowa. Warszawa, Instytut Badań Interdyscyplinarnych „Artes Liberales” Uniwersytetu Warszawskiego, Wydawnictwa Uniwersytetu Warszawskiego, 2011, s. 141-171.

Cyhun, Genadz'. Prastora movy. Moǔnyâ suvâzì. Gìstoryâ sloǔ: vybranyâ pracy. Mìnsk, Belaruskaâ navuka, 2018.

Cyhun, Genadz'. [Rec.]. „Brasławszczyzna. Pamięć i współczesność. T. 2. Słownictwo dwujęzycznych mieszkańców rejonu (Słownik brasławski)”. Belaruskaâ lìngvìstyka, nr 67, 2011, s. 179-182.

Draǔnìckì, Âs'ka. Kamarova. Maâ Vilenščyna. Pastavy, Sumežža, 2004, s. 3-30.

Engelking, Anna. „Kategoria mieszana mowa w ujęciu mieszkańców pogranicza językowego na Grodzieńszczyźnie. Spojrzenie antropologa”. Z Polskich Studiów Slawistycznych. Seria 12. Językoznawstwo. Prace na XV Międzynarodowy Kongres Slawistów w Mińsku 2013. Warszawa, Polska Akademia Nauk, Komitet Słowianoznawstwa, 2012, s. 21-29.

Engelking, Anna. „Po swojemu, po polsku, po białorusku. Praktyka językowa a poczucie tożsamości narodowej prawosławnych mieszkańców pogranicza polsko-białoruskiego". Oblicza lokalności. Różnorodność miejsc i czasu. Red. Joanna Kurczewska. Warszawa, IFiS PAN, 2006, s. $26-46$.

Engelking, Anna. „Tożsamość «tutejsza» na wielojęzycznym pograniczu. Spostrzeżenia na przykładzie parafii nackiej”. Język a tożsamość na pograniczu kultur. Red. Elżbieta Smułkowa, Anna Engelking. Białystok, Katedra Kultury Białoruskiej Uniwersytetu w Białymstoku, 2000, s. $17-23$.

Èrker, Aksana. „Specifika imennyh paradigm v belorusskom smešannom govore na balto-slovânskom pogranič'e". Balto-slovânskie issledovaniâ, nr 18, 2013, s. 193-229.

Èrker, Aksana. „Sposoby vyraženiâ prošedšego vremeni v belorusskom smešannom govore na balto-slovânskom pogranič'e”. Slavica Bergensia, nr 12, 2014, s. 130-149.

Gil', Mìhal, Âs'ka Draǔnìckì. „Kamarova (Kamaroǔščyzna)”. Bylyâ sâdziby ì parkì Paazer 'â. Mâdzel'ščyna. Pastavy, Sumežža, 2008, s. 22-31.

Golachowska, Ewa. Jak mówić do Pana Boga? Wielojęzyczność katolików na Białorusi na przetomie XX i XXI wieku. Warszawa, Instytut Slawistyki PAN, Wydawnictwo Agade Bis, 2012.

Golachowska, Ewa. „Język modlitwy na współczesnej Grodzieńszczyźnie”. Językowe i kulturowe dziedzictwo Wielkiego Księstwa Litewskiego. Księga jubileuszowa na 1000-lecie Litwy. Red. Zofia Sawaniewska-Mochowa, Jolanta Mędelska. Bydgoszcz, Uniwersytet Kazimierza Wielkiego w Bydgoszczy, 2010, s. 222-239.

Guszczewa, Olga. „Zakres użycia języka rosyjskiego i jego oddziaływanie na gwary białoruskie i polszczyznę w rejonie brasławskim". Brasławszczyzna. Pamięć $i$ współczesność. T. 1. Historia regionu. Charakterystyka socjolingwistyczna. Świadectwo mieszkańców. Red. Elżbieta Smułkowa. Warszawa, Instytut Badań Interdyscyplinarnych „Artes Liberales” Uniwersytetu Warszawskiego, Wydawnictwa Uniwersytetu Warszawskiego, 2011, s. 214-246. 
Karaś, Halina. Polska leksykografia gwarowa. Warszawa, Wydział Polonistyki UW, 2011.

Lemâšonak, Uladzìmìr. „Akupacyjny rèžym”. Pamâc'. Mâdzel'skì raën. Red. Âraslaǔ Genryhaviě Zvâruga. Mìnsk, Belaruskaâ èncyklapedyâ, 1998, s. 187-188.

Radzik, Ryszard. „Język jako wyznacznik tożsamości Białorusinów”. Język a tożsamość na pograniczu kultur. Red. Elżbieta Smułkowa, Anna Engelking. Białystok, Katedra Kultury Białoruskiej Uniwersytetu w Białymstoku, 2000a, s. 71-82.

Radzik, Ryszard. Między zbiorowościa etniczna a wspólnota narodowa. Białorusini na tle przemian narodowych w Europie Środkowo-Wschodniej XIX stulecia. Lublin, Wydawnictwo Uniwersytetu Marii Curie-Skłodowskiej, 2000b.

Smalanczuk, Aleś. „Narodowy i kulturowy rozwój Brasławszczyzny w XIX wieku”. Brasławszczyzna. Pamięć i wspótczesność. T. 1. Historia regionu. Charakterystyka socjolingwistyczna. Świadectwo mieszkańców. Red. Elżbieta Smułkowa. Warszawa, Instytut Badań Interdyscyplinarnych „Artes Liberales” Uniwersytetu Warszawskiego, Wydawnictwa Uniwersytetu Warszawskiego, 2011, s. 47-73.

Smułkowa, Elżbieta. Białoruś i pogranicza. Studia o języku i społeczeństwie. Warszawa, Wydawnictwa Uniwersytetu Warszawskiego, 2002.

Smułkowa, Elżbieta. Moje pogranicza w historii, języku i wspomnieniach. Warszawa, Instytut Slawistyki PAN, Slawistyczny Ośrodek Wydawniczy, 2016.

Smułkowa, Elżbieta. „Problem zapożyczeń w warunkach rozpadającej się społecznej wielojęzyczności. Rozważania wstępne”. Studia Białorutenistyczne, nr 4, 2010, s. 283-295.

Smułkowa, Elżbieta, red. Brasławszczyzna. Pamięć i współczesność. T. 1. Historia regionu. Charakterystyka socjolingwistyczna. Świadectwo mieszkańców. Warszawa, Instytut Badań Interdyscyplinarnych „Artes Liberales” Uniwersytetu Warszawskiego, Wydawnictwa Uniwersytetu Warszawskiego, 2011.

Smułkowa, Elżbieta, red. Brasławszczyzna. Pamięć i współczesność. T. 2. Słownictwo dwujęzycznych mieszkańców rejonu (Słownik brasławski). Warszawa, Wydawnictwa Uniwersytetu Warszawskiego, 2009.

Smułkowa, Elżbieta, Anna Engelking, red. Pogranicza Białorusi w perspektywie interdyscyplinarnej. Warszawa, Wydawnictwo DiG, 2007.

Tolstaâ, Svetlana. [Rec.]. „Brasławszczyzna. Pamięć i wspótczesność. T. 1. Historia regionu. Charakterystyka socjolingwistyczna. Świadectwo mieszkańców. Red. nauk. Elżbieta Smułkowa. Warszawa: Instytut Badań Interdyscyplinarnych „Artes Liberales” Uniwersytetu Warszawskiego, 2011, ss. $659+1$ płyta CD. T. 2. Stownictwo dwujęzycznych mieszkańców rejonu (Słownik brasławski). Red. nauk. Elżbieta Smułkowa. Warszawa: Wydawnictwa UW, 2009, ss. 765". Rocznik Slawistyczny, 61, 2012, s. 190-198.

Wiemer, Björn. „Mowa Prosta (Präliminaria zu einer strukturellen Beschreibung)”. Beiträge der Europäischen Slavistischen Linguistik (POLYSLAV), nr 6, 2003, s. 227-237.

Wiemer, Björn. „Osuŝestvlenie soglasnyh v «move prostoj» kak pokazatel' izmenenij v usloviâh kontaktov". Acta Baltico-Slavica, nr 30, 2006, s. 439-452.

Zielińska, Anna. Mniejszość polska na Litwie kowieńskiej. Studium socjolingwistyczne. Warszawa, Slawistyczny Ośrodek Wydawniczy, 2002.

Zielińska, Anna. „Pogranicze wschodnie i zachodnie. Wspólnota doświadczeń”. Polskie dziedzictwo kulturowe na Kresach. Red. Ewa Dzięgiel. Warszawa, Instytut Języka Polskiego PAN, Wydawnictwo Semper, 2012, s. 395-404.

Zielińska, Anna. [Rec.]. „Brasławszczyzna. Pamięć i wspótczesność. T. 1. Historia regionu, charakterystyka socjolingwistyczna, świadectwo mieszkańców. Red. nauk. Elżbieta Smułkowa. Insytut Badań Interdyscyplinarnych „Artes Liberales” Uniwersytetu Warszawskiego, Wydaw- 
nictwa Uniwersytetu Warszawskiego, Warszawa 2011, ss. 659”. Acta Baltico-Slavica, nr 37, 2013, s. 601-612.

Zielińska, Anna. „Zmiana, zachowanie i utrata języka w rodzinach na pograniczu słowiańsko-bałtyckim”. Tożsamość - Język - Rodzina. Z badań na pograniczu słowiańsko-battyckim. Red. Anna Engelking, Ewa Golachowska, Anna Zielińska. Warszawa, Slawistyczny Ośrodek Wydawniczy, 2008, s. 165-176.

Żebrowska, Anna. Komarowszczyzna. Język pogranicza białorusko-polsko-litewskiego. Poznań, Wydawnictwo Naukowe UAM, 2019. 
